\title{
АЛТЕРНАТИВНА БИБЛИОТЕКА СТАРТИТ ЦЕНТРА
}

\section{Сажетак}

На трагу алтернативних библиотека кроз историју, али и оних које у савременом тренутку постоје у свету, рад описује алтернативну библиотеку у центру Београда намењену програмерима, дизајнерима, предузетницима и запосленима у маркетингу који се баве информационим технологијама. Под окриљем Стартит центра у Савској улици број 5 ова библиотека постоји од 2016. и има вишеструку функцију и значај. Посетиоци центра у прилици су да приликом посете разгледају полице библиотеке, при чему је на овај начин простор максимално искоришћен, а књиге су лако доступне читаоцима. Ова библиотека има и ПР функцију центра зато што привлачи нове кориснике жељне знања, а знање којим снабдева појединце који учествују у домаћој привреди свакако има позитиван допринос за домаћу економију.

Кључне речи: библиотека, алтернативна библиотека, полица, простор библиотеке, филозофија простора, глобализација, економска улога библиотеке, Стартит центар.

\section{1. О појму алтернативне библиотеке}

Сам појам алтернативности подразумева постојање већег броја могућности. Отуда покушај да се дефинише алтернативна библиотека представља озбиљан захтев. Алтернативна библиотека јесте заједнички именитељ који обухвата велики број међусобно различитих могућности: кроз историју - дијахронијски, али и оних међусобно најразличитијих у савременом тренутку - синхронијски. Кроз историју гледано, алтернативна библиотека су и монденски и грађански салони средње Европе у седамнаестом и осамнаестом веку, и кафеи у Мађарској у деветнаестом веку, и касине у Србији, које су претече модерних читаоница. Алтернативна библиотека може се данас наћи на леђима магарета упрегнутог кроз стрме гудуре планинских предела, као и на аеродромима, бродовима и станицама метроа. (Вранеш 2010:51, Софронијевић/Андоновски 2011:69) 
Оно што је заједничко и основно начело у организацији оваквих библиотека јесте хуманост као основни квалитет. (Вранеш 2010: 51) Поред тога, до изражаја долазе и: 1) инвентивност у организацији инвентара и простора, као и 2) спонтаност - а оба са циљем да библиотека и корисници успоставе што непосреднији однос.

Алтернативна библиотека не поставља пред читаоца никакве захтеве у погледу новчане надокнаде; она је јавна и отворена за свакога. За циљ има примарно то да информацију и знање учини што доступнијим члановима локалне заједнице.

Порединвентивности, једанод квалитетасвакако бимогаода буде и иновативност овакве врсте библиотека и њихових оснивача, односно библиотекара. У првом реду због тога што ове библиотеке настоје да подмире потребу читалаца за новином, за праћењем дешавања у земљи и свету у различитим областима науке, књижевности, технологије, за праћењем свега онога што се може назвати трендом у области информисаности. Премда овај идеал никада у потпуности није достижан јер је свака библиотека у погледу ресурса ограничена алтернативна библиотека тежи томе да задовољи новонастале потребе читалаца - онолико колико је то могуће. Са друге стране, уколико се дезидерати корисника не поштују барем у мери изводљивости, извесно је да ће њихово интересовање, као и број пружених услуга и посета библиотеци бити у стагнацији. (Вранеш 2010:52)

\section{2. Библиотека Стартит центра}

Алтернативна библиотека Стартит центра представља један од покушаја да се задовоље потребе чланова локалне заједнице који су запослени у ИТ сектору или су у фази преквалификације. Пре свега оних који се интересују за технологију, дизајн, бизнис и маркетинг. Будући да технолошка индустрија у нашој земљи доживљава убрзан развој и напредак и да постоји изражена потреба за стручним кадром, постоји такође и велика потреба за образовањем ових стручњака, али и њихова лична потреба да се константо усавршавају и унапређују стручна знања и вештине, не би ли остали у току са развојем привреде. Формални курсеви и образовање организовани су и понуђени на уни- 
верзитетима државним и приватним. Са те стране, програми су унапред испланирани и структурирани и многи од њих имају статус престижних. Домаће формално образовање у овом погледу задовољава потребе тржишта, а нуди такође и могућност избора.

Управо на основу убрзаног развоја домаће ИТ индустрије, а поред тога и великог броја домаћих стручњака у иностранству, може се уочити да наше формално образовање у великој мери прати и задовољава потребе привреде. Свакако да ово саодношење никада није у савршеним пропорцијама, пре свега због великог броја учесника у просецу образовања (понајвише студената са најразличитијим индивидуалним афинитетима), али могло би се приметити да су честе критике формалног образовања у одређеним случајевима ипак претеране. Домаћи проналазачи, мислиоци, писци, ствараоци и стручњаци доказали су да им то образовање ни у ком смислу није било препрека у научном и ументичком стваралаштву.

Поред могућности да се професионално усавршава у формалном смислу, појединцу остаје отворена могућност и да се самостално усавршава. Да се приближава замишљеном савршенству, тј. идеалу који је себи зацртао, и да оно што сматра да му формално образовање није пружило надокнади кроз самосталан рад, истражујући у складу са својим личним склоностима и интересовањима. Поље које представља поље алтернативности, у било ком образовању, и у било којој индустрији, јесте поље неформалног образовања. Овде је од великог значаја управо библиотека. Било да је лична, електронска, градска или ма која друга, библиотека има за циљ да удовољи радозналости и истраживачкој машти, да инспирише, да подмири једну меру потреба за новим знањем.

Јединствена библиотека на нашим просторима, што се тиче избора штива, али и простора у коме је инвентар организован јесте управо библиотека Стартит центра. Овај центар налази се у приземљу зграде у улици Савска 5, у центру Београда, преко пута главне железничке станице. Ово је место које служи за окупљање заједница са домаће ИТ сцене. У овом простору се у оквиру различитих догађаја, али и кроз рад на различитим пројектима окупљају програмери, дизајнери, стручњаци за маркетинг, предузетници, а сви са циљем да поделе међусобно знање. Заједнице које редовно организују догађаје су Вордпрес, Маркетинг, Ју-Икс, Јава скрипт и друге. Сви они користе простор центра зарад окупљања и едукације. 
Као што су грађанске касине била алтернативна стецишта грађана окупљених просветитељским настојањима, тако је и простор Стартит центра алтернативно место у коме се окупљају грађани заинтересовани за технологију и предузетништво. (Вранеш 2010:51)

Свакодневно се део простора повољно изнајмљује појединцима који су самостални предузетници и желе да раде и сарађују са другим колегама, уче од њих и међу собом размењују искуства. Оваква врта простора назива се на енглеском коворкинг простор (coworking) при чему се ова реч не преводи, а социолингвистичке разлоге за ово објаснићемо до краја текста.

Идејни творац који стоји иза овако осмишљеног и организованог простора јесте организација СЕЕ ИЦТ (South East Europe Information and Communication Technologies), која представља непрофитну организацију која има за циљ да повеже професионалце из области информационих технологија и подстакне раст и развој домаће привреде и економије.

Основне вредности ове билиотеке изнете су у чланку на блогу центра у коме је објављено отварање библиотеке: „Знање за све“.

Формирање фонда омогућили су и помогли спонзори, донатори центра, а то су пре свега фирме као што су Хјуманити (Humanity) и Севн Бриџиз (Seven Bridges)², али и појединци који су донирали прочитане књиге из својих приватних библиотека.

Библиотека такође прима донације у књигама које спадају у неке од наведених категорија, као што је и наглашено на сајту центра.

\section{3. Економска улога библиотеке}

20. јануара 2016. под окриљем Стартит центра И СЕЕ ИЦТ организације отворена је библиотека бесплатна за све кориснике, са литературом (часописима и књигама) из области технологије, дизајна, бизниса, економије и личног развоја. На почетку библиотека је имала око 150 наслова, а до данас тај фонд се удвостручио. Ово је

1 Текст је објављен у оквиру блога на веб-страници: https://startit.rs/znanje-za-sve-otvaramo-zajednicku-biblioteku-startit-centra/

2 Поред ових ту су и фирме: Нордеус, Аипикс, ВРХ Солушнс, Факултет за финансије и администрацију и др. 
још увек скроман инвентар, али оваква библиотека ипак има вишеструку економску функцију:

1) Омогућава непосредан и брз приступ информацијама и тиме доприноси компетентности стручњака који су запослени у домаћој привреди.

2) Окупља чланове у заједницу у којој се размењују и деле знања.

3) ПР библиотека центра. ${ }^{3}$

Приступ информацијама јесте незаобилазни фактор за економски напредак заједнице у којој професионалци раде. Ова врста библиотеке и те како би могла значајно утицати на привредни напредак и раст домаће економије кроз удовољавање потребама за доживотним образовањем стручног кадра. У том смислу се анализа повраћаја улагања не може сагледати дефинитивно, али је допринос известан.

Догађаји организовани у центру кроз ивент маркетинг отварају и приближавају библиотеку корисницима. ${ }^{4}$ Учесници семинара, курсева, предавања и других врста окупљања у заједничком простору, у коме су и мини-амфитеатар и библиотека, имају прилику да присуствујући догађају, непосредно разгледају и полице библиотеке и прелистају књиге. Библиотека такође има и ПР функцију тако што сам центар и спектар понуђених знања, догађаја и курсева, који су или бесплатни или субвенционисани, приближава потенцијалним полазницима и привлачи нове посетиоце центра. Библиотека је тако и врста алата у маркетингу, али са друге стране управо захваљујући добром маркетингу центра, ова библиотека, иако скромна, блиска је корисницима.

Библиотечком каталогу може се приступити онлајн. Књиге се могу одабрати и резервисати путем интернета, како се заказује и време преузимања. Чланарина у овој библиотеци је бесплатна, читав фонд доступан је јавности, а мото оснивача је: „Знање за све”. Дакле основна начела на којима је библитека заснована јесу слобода избора, доступност и бесплатност. Пошто је и сама организација непрофитна, принцип на коме почива суштински јесте - хуманост. Услови

3 Да бисмо дошли до закључака о економској функцији библиотеке подстицај смо потражили у зборнику резимеа са Међународног научног скупа Економска улога библиотека у савременом друштву, ур. Александра Вранеш, Београд: Филолошки факултет., 2004.

4 Више о приближавању библиотеке корисницима видети у Софронијевић/Андоновски 2011. 
приступа се не постављају никоме. Ово је алтернативна библиотека отворена за све. Принципи на којима опстају овакве алтернативне заједнице јесу: бесплатност, самодовољност, солидарност, аутономност, демократичност, еколошка и вегетаријанска одрживост, бесплатна економија. (Вранеш 2010:54)

\section{4. Уређење простора}

Значење речи библиотека потиче од грчког назива за полицу. Старогрчке морфеме biblion (књига) и theke (ковчег, орман) заједно означавају место за чување књига. И енглески термин library настао је модификацијом латинских израза liber (књига, писмо), односно librarium (ормар за књиге). Намена овог сабиралишта и хранилишта јесте не само кумулација знања, већ и подстицај за даље интелектуално стваралаштво, оно које тек треба да настане и изврши утицај на друштво, културу и економију наше земље. Отуда и скроман обим билиотечког фонда о коме пишемо није занемарљив јер представља зачетак нечега чему се крајњи домети не могу сасвим предвидети ни одредити. (Божић 2012:295)

У вези са полицама незаобилазно је споменути стил њихове организације и визуелну естетику у складу са којом су уређене. Књиге су поређане на полицама које су уређене у духу најновије моде уређивања ентеријера која долази из Силицијумске долине. Овде су поред књига на полицама и други предмети који служе декорацији и креирању жељеног ефекта и визуелног идентитета. Ту су портрет Николе Тесле, шоље са принтом и аутомобилска таблица на којој пише „Сан Франциско”. Овакво уређење простора од вишеструког је значаја и доприноси формирању идентитета заједнице. ${ }^{5}$ Покушаћемо да пружимо нека од објашњења зашто је то тако.

Силицијумска долина представља технолошки најнапреднију регију у свету. Место у коме су се у претходним годинама догодиле најзначајније иновације у области технологије. И место које се сматра најплоднијим у погледу идеја, али и могућности да се ове идеје реализују, људских слобода и стециште је ИТ стручњака из целог света.

5 Више о утицају библиотеке и простора на формирање идентитета видети у Вранеш 2010 и Димитријевић 2015. 
3бог свега овога битно је да се дух Силицијумске долине осети у Београду. И зато је неопходна имагинарна веза са овим калифорнијским пределом. Бунт јесте у извесној мери својствен алтернативној библиотеци и оваквим врстама организација, али ово није израз никаквог бунта, већ пре свега израз тежње ка највећим могућим и непредвидивим дометима, остварењу подухвата који би могли променити свет. Са ових мотива постоји и тежња ка имагинарној повезаности са Силицијумском долином. Оваква врста замисли спада у домен имагинарне географије - замишљене везе између одређених простора, тј. тачака на карти света. ${ }^{6}$

За објашњење ове везе и појма имагинарне географије битни су појмови постмодерна и глобализација. У модерни је на уштрб категорије простора фаворизована категорија времена. Историјска епистемологија, која проучава историјска и културна дешавања кроз време, доминирала је у модерној мисли од просветитељства до Маркса. Са тим је у вези једна од најупечатљивијих идеја овог раздобља, а то је Хегелова идеја човековог напретка кроз историју. Према овој врсти теоријског сагледавања друштвених дешавања, простор је сасвим занемарен, тако да произилази да је невидљив или празан, односно фиксиран и недијалектичан.

Читав претпостављени напредак људске врсте дешавао се независно од простора. Постмодерна, са друге стране, прави теоријски заокрет ка проучавању географије, зона, односно простора и опште узев - спациоцепција, као и обликотворних друштвених сила које учествују у њиховом формирању. Тако се савремене студије културе баве и читањем значења уписаних у различите просторе.

\section{5. Глобализација и културна веза са Калифорнијом}

Тежња за културним уједињењем Београда и Силицијумске долине, ако посегнемо за Гиденсовом теоријом, јесте израз глобализације. Сама по себи глобализација представља изузетно сложен и слојевит процес, са присталицама и противницима, са добробитима, али и мрачном страном. Имајући све то у виду, може се ипак уочити наглашена

6 О имагинарној географији и постмодерном схватању простора пише Божић 2012. 
економска и идејна тежња за приближавањем ове две регије. Кулурна чежња можда је овде у другом плану, јер се овде и те како инсистира на јачању локалне заједнице и домаће економије. Веза локалног и глобалног вишеструко је осмишљена. То је имагинарна мрежа путева и директних веза на карти света која повезује тачке наочиглед неповезане директно, природним путем. Зато се и регистарска таблица из Сан Франциска на полицама библиотеке може сматрати изразом једне замисли о смеру кретања, али пре свега о идејној дестинацији и вези.

У вези са овако уређеним простором, стилом, али и као глобална и практична мода из Калифорније јесте и скромност. За појам алтернативне библиотеке везује се калвинистичка осуда луксуза и жеља да се умање разлике између богатих и сиромашних. (Вранеш 2010:52) Идеолошки разлози могу бити хришћански, демократски, у крајњем реду и пре свега хумани. Алтернативна библиотека тежи томе да максимално искористи простор и ресурсе, који су свакако ограничени.

Скромност простора у коме се налазе полице библиотеке коју описујемо може се тумачити директно као израз миленијумске скромности, односно моде настале пре свега после краха њујоршке берзе. Ова мода са једне стране представља израз оскудице, настале као последица финансијске кризе у Америци и шире (и ово је релативно), али и практичног опреза у располагању материјалним средствима. Оваква мода такође има за циљ да не истиче разлике између богатих и сиромашних, у вези је са калифорнијским либералним идејама о грађанским слободама, као и уверењима о неспутаној друштвеној мобилности.

И поред свих ових глобалних утицаја, можда је основни ипак утицај домаће културе на којој почивају вредности истакнутих мислилаца. Скромност Николе Тесле, чији портрет краси и полице овог центра, почива на вредностима из домаће културе и може се рећи православних хришћанских утицаја. Теслина идеја јесте и идеја центра о стварању, о проналасцима који би служили добробити човечанства, без икакве намере о профиту. Идеја да посвећеност раду и реализацији идеја не захтева нарочит луксуз. Као и идеја да се у Србији могу остварити достигнућа међународних и глобалних размера, у корак са најразвијенијим светским центрима.

Културна веза са Силицијумском долином је вишеструка. Поред категорија маште које спадају у домен имагинарне географије, 
битна је такође и радна култура која је нераскидиво повезана са уређењем простора. Снажна идентификација са предузетницима из Силицијумске долине, са једне стране је битна због тога што су генерално средства, када се тежи уштеди ресурса и економичности приликом организације и најбогатијих предузећа, увек ограничена, а са друге стране, представља извор мотивације за рад и напредак кроз угледање на успешне примере у најразвијенијим светским центрима.

\section{6. Филозофија простора}

Миленијумска скромност може се довести у везу и са супкултуром хипстера, која понекад има и негативан призвук и значење јер се доводи у везу са позирањем, што овде није случај. Скромност и једноставрност у директној је економској вези са последицама експлодирања економског мехура и настанком светске финансијеске кризе 2008. Предузетници, нарочито они из САД-а више се не задужују не би ли оставили утисак на пословне партнере и не труде се да уштеде на свим могућим ресурсима уколико је могуће да их бесплатно добију и да бизнис функционише без додатних трошкова и улагања. Зато је практичније простор изнајмити у центру града, у прометном делу, који је довољно близу свима запосленима, како би могли да се на посао врате и после вечере. Такође, није више део професионализма то како изгледају просторије, већ квалитет посла који се обавља и висина профита који се остварује. ${ }^{7}$

Са модом која долази из Сан Франциска није у вези само уређеност полица него и читавог простора Стартит центра. Управо овај отворени простор (open space), како га називају, пружа полазницима курсева и семинара, хакатона и осталих догађаја међусобну комуникацију и сарадњу, могућност размене знања и искустава и представља место сусрета. Сва дешавања и радне активности одвијају се у просторији на једном нивоу. Ту се налазе сала за састанке, која је одвојена прозирним стакленим вратима од остатка центра. Овај прозирни зид представља звучну и естетску баријеру, али у исто време, његова транспарентност

7 О овоме видети текст Пола Грејема, програмера, предузетника и инвеститора, на вебстраници коју наводимо и у списку литературе: http://paulgraham.com/start.html 
доприноси повезаности свих делова простора и њиховој уједињености. Даље, ту се налазе амфитеатар и слушалиште са пројекторским платном и сценом, као и кухиња, библиотечки кутак и простор за рад самосталних предузетника. Сви ови делови простора чине кутке, односно издвојене зоне у оквиру заједничког и јединственог простора.

Са овим у везу може се довести и филозофија простора Мишела Фукоа и значајан појам који је увео, а то је појам хетеротопије. ${ }^{8}$ За Фукоа су хетеротопије апсолутно друкчији и друштвено разнолики простори, представљају могућност, неочекивано, непланирано - ad hoc реаговање на одређене околности и стварање нове, смисаоне и умрежене целине. Библиотеке су, као и музеји, према Фукоу, хетеротопије. То су места акумулације простора, обличја и времена и сама су због тога заштићена од пролазности и пропадања, то су места изван времена. Хетеротопије у једном простору обједињују фрагменте и чиниоце стварности који су изван њих узајамно неспојиви. То су простори који су изван свакодневнице и другачији.

Ова библиотека се зато налази у постмодерном простору имагинарне географије. Утиску кутлурне повезаности доприносе и називи простора који се не преводе, а сви имају за утисак да ојачају и подстакну културну упућеност на глобално тржиште. Зато се заједнички простор за рад назива coworking простором илити open space.

\section{7. Закључак}

Простор Стартит центра, заједно са својом библиотеком, представља управо једну хетеротопију, према филозофији Мишела Фукоа. Као место сусрета и место за размену знања и идеја, место за едукацију, јесте и место формирања идентитета чланова заједнице. Место где се везе међу члановима одржавају и негују и она има прилику да се развија и расте. Динамично окружење у коме се заједница развија и где чланови долазе да раде, подрже једни друге, информишу се, потраже инспирацију и сараднике за даљи рад утиче на формирање јединствене атмосфере и за рад библиотеке. Библиотечке услуге понуђене сучлановима заједнице на месту где проводе највише времена. Они су приликом посете предавањима или за време радног

8 О овоме детаљно Божић 2012. 
бораква у Стартит центру у прилици да инвентар виде на полицама, да књиге узму у руке и прелистају, пре него што их позајме, као и да разговарају са библиотекарима и другим корисницима. Оваква атмосфера одудара од оне на коју смо навикнути у библиотекама у којима се подразумевају мир и тишина, па и оним већим и далеко богатијим, у којима је фонд на срећу обиман, али се нажалост, изгубила могућност да самостално разгледамо полице и прелиставамо књиге, а можда и да поразговарамо са другим корисницима.

\section{Извори и литература:}

Божић, Јадранка М. „Библиотека као хетеротопија - неместо амбијенталне целине Косанчићев венац" у Гласник Народне библиотеке Србије, година 13, број 1 , Београд, 289-300.

Вранеш, Александра. Економска улога библиотека у савременом друштву, зборник резимеа са међународног научног скупа. Београд: Филолошки факултет, 2004.

Вранеш, Александра. „Алтернативна библиотека“ у Књига и језик у развоју савременог друштва, Београд, 51-56

Гиденс, Ентони. Социологија. Београд:Економски факултет, 2007.

Димитријевић, Мирослав. „Центар алтернативне свести“ у Зборник радова Факултета техничких наука број 11, Београд, 1955-1958.

Софронијевић/Андоновски, Адам/Јелена. „Приближити библиотеку корсницима: библиотеке у алтернативним просторима“" у Инфотека: часопис за информатику и библиотекарство, август 2011, 69-75.

https://startit.rs/startit-centar/, сајт Стартит центра.

http://paulgraham.com/start.html, есеј Пола Грејема.

Божић 2012: Јадранка М. Божић, „Библиотека као хетеротопија - неместо амбијенталне целине Косанчићев венац" у Гласник Народне библиотеке Србије, година 13, број 1, Београд, 289-300.

Вранеш 2004: Економска улога библиотека у савременом друштву, зборник резимеа са међународног научног скупа. Београд: Филолошки факултет, 2004.

Вранеш 2010: Александра Вранеш, „Алтернативна библиотека“ у Књига и језик у развоју савременог друштва, Београд, 51-56.

Гиденс 2007: Ентони Гиденс, Социологија, Београд: Економски факултет.

Димитријевић 2015: Мирослав Димиријевић, „Центар алтернативне свести“ у Зборник радова Факултета техничких наука број 11, Београд, 1955-1958.

Софронијевић/Андоновски 2011: Адам Софронијевић и Јелена Андоновски, „Приближити библиотеку корсницима: библиотеке у алтернативним просторима“ у Инфотека: часопис за информатику и библиотекарство, август 2011, 69-75.

https://startit.rs/startit-centar/, сајт Стартит центра.

http://paulgraham.com/start.html, есеј Пола Грејема. 
Jelena Jevtić

\title{
STARTIT CENTER ALTERNATIVE LIBRARY
}

\begin{abstract}
Summary
On the trail of alternative libraries through history, but also those that exist in the modern world, this paper describes an alternative library in the center of Belgrade intended for developers, designers, entrepreneurs and and marketing employees dealing with information technology. Under the auspices of the Startit Center in the street Savska 5, these libraries exist since 2016 and have multiple function and significance. Visitors have the opportunity to visit the library when visiting the center, whereby space is maximally exploited in this way, and books are readily available to readers. This library also has PR function of the center because it attracts new individuals eager to learn, and the knowledge provided by individuals participating in the domestic economy certainly has a positive contribution to the domestic economy.
\end{abstract}

Key words: library, alternative library, shelf, library space, space philosophy, globalization, the economic role of the library, the Startit Center. 